\title{
Sisyrinchium rosulatum E.P.Bicknell (Iridaceae): new record of a naturalized species in Bhutan
}

\author{
Phub Gyeltshen ${ }^{1}$, Dipankar Borah' ${ }^{2}$ and A. P. Das \\ Department of Botany, Rajiv Gandhi University, Rono Hills, Doimukh 791112, Arunachal Pradesh, India \\ ${ }^{1}$ Department of Forest and Park Services, Ministry of Agriculture and Forest, Nubi33001, Trongsa, Bhutan \\ ${ }^{2}$ Author for correspondence, e-mail: dipankar.borah@rgu.ac.in
}

[Received 12.05.2019; Revised 18.06.2019; Accepted 24.06.2019; Published 30.06.2019]

\begin{abstract}
Sisyrinchium rosulatum E.P.Bicknell (Iridaceae, Iridoideae, Sisyrinchieae), a native of South America, is recorded and described here as a newly naturalized species for the flora of Bhutan.
\end{abstract}

Key words: Sisyrinchium rosulatum, Bhutan, Naturalization, New record

\section{INTRODUCTION}

Sisyrinchium L. (Iridaceae, Iridoideae, Sisyrinchieae) is the most diverse genus in the tribe consisting of approximately 200 species (Henderson 1976; Rudall et al. 1986), and is mostly distributed in the new world (Henderson 1976; Cholewa \& Henderson 1984; Nicolella $\&$ Ardenghi 2013). The taxonomy of Sisyrinchium is complex (Chauveau et al. 2011) and hence, taking detailed field notes, remaining extra-cautious while preserving specimens, and by using large samples to evaluate multiple characters help in identification of species and filling the taxonomic gaps (Henderson 1976) are important. It prefers wet to dry grasslands, rocky and sandy soils, roadsides, grazed and burnt fields (Bicknell 1899). In July of 2017 an unfamiliar species of Sisyrinchium was collected from Trongsa District of central Bhutan. After perusal of relevant literatures (Bicknell 1899; Goldbatt et al. 1990; Yamaguchi \& Hirai 1987; Henderson 1976; Chauveau et al. 2011; Shin et al. 2016) it was identified as Sisyrinchium rosulatum E.P.Bicknell. It is native to the southern part of North America and some part of South America (Bicknell 1899; Goldbatt \& Manning 2008; Nicolella \& Ardenghi 2013) and is reported as an invasive species in Korea (Shin et al. 2016), and also exotic to 22 countries (PlantNET 2013). For the Flora of Bhutan Noltie (1994) recorded a total of 13 species representing five genera (Iris, Gladiolus, Crocosmia, Eleutherine, Belamcanda). Now, with the addition of Sisyrinchium rosulatum, the numbers for genus and species increased to six and 14, respectively in this family for the flora of Bhutan.

\section{Taxonomic treatment:}

Sisyrinchium rosulatum E.P.Bicknell in Bull. Torr. Bot. Cl. 26: 228. 1899. Sisyrinchium brownie Small in Contrib. New York Bot. Gard. 327: 330. 1931. Sisyrinchium exile E.P. Bicknell in Bull. Torr. Bot. Cl. 28: 573 - 574. 1901.

TYPE: MNHN-P-P00672523 (P). 

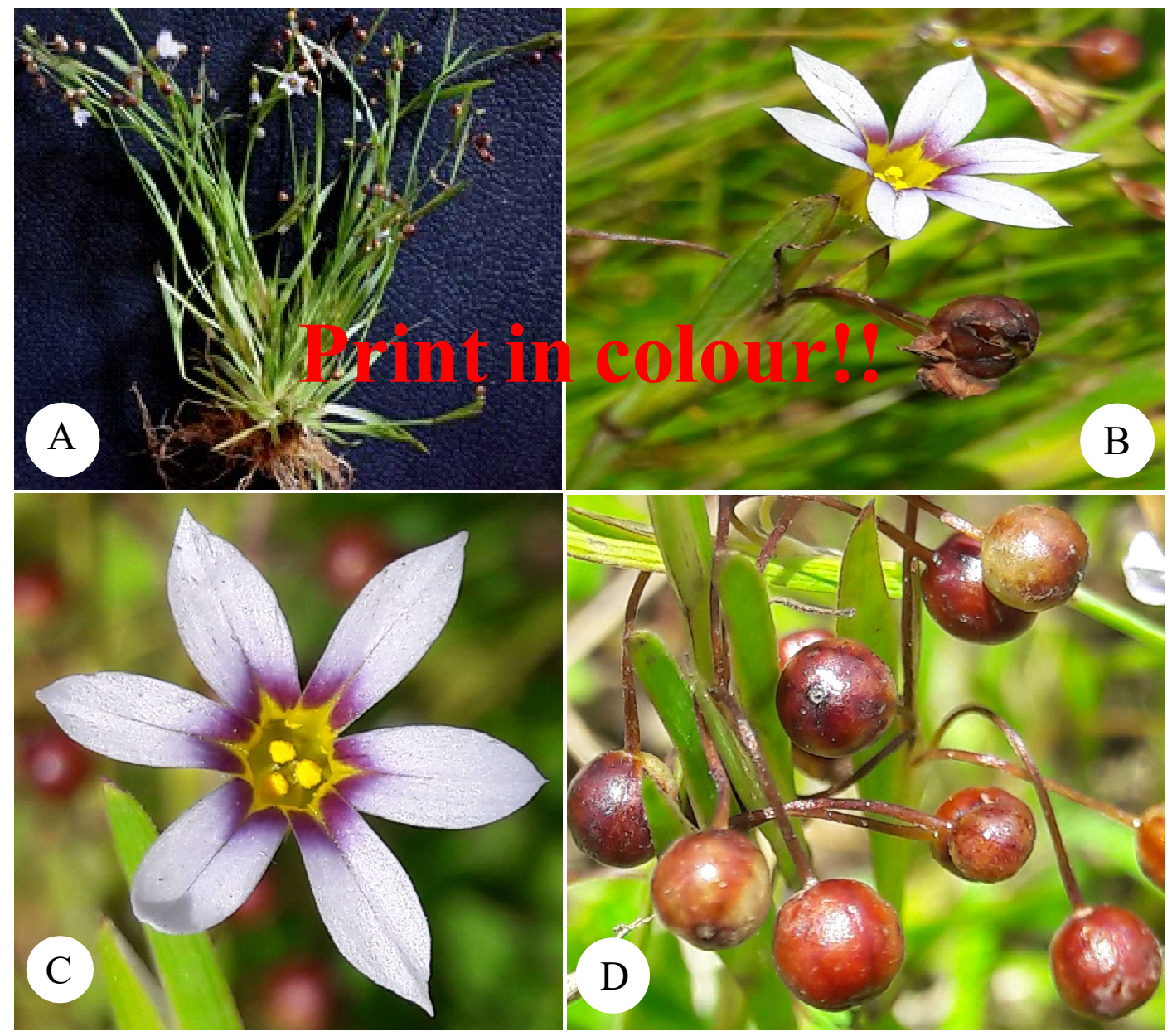

PLATE - I. Sisyrinchium rosulatum E.P. Bicknell: A. Habit; B. Part of the inflorescence showing mode of flower bearing; C. Top view of flower; D. Fruits. [Photos by Phub Gyeltshen at Bumthang, Bhutan on 12 June 2015]

SPECIMENS EXAMINED: BHUTAN. Bumthang, $27.592167^{\circ} \mathrm{N} 90.728673^{\circ} \mathrm{E}, 2622 \mathrm{~m}$ elevation, June 25, 2015, Phub Gyeltshen H106 (THIM; Figure 1); Thimphu, 27.51283 ${ }^{\circ}$ N $89.644973^{\circ}$ E, 2457m elevation, July 15, 2017, Phub Gyeltshen H201 (THIM).

Rosette annual herb, $3-35 \mathrm{~cm}$ tall, glabrous, tufted, growing in small clumps. Stem glabrous, branches $1-3-4$ or un-branched, simple with $1-3(-4)$ nodes; internodes $15-80 \times 0.6$ $-2 \mathrm{~mm}$, shorter than its proximal leaves, stem colour similar to leaves, first node with 1 or 2 branches, usually middle internodes longer than the extreme ones. Leaves $2-8$, grass -like, $1.2-25 \times 0.1-0.6 \mathrm{~cm}$, clasping, erect, alternate, sessile, linear-lanceolate, entire, narrowly acuminate, both sides glabrous, bases not persistent in fibrous tuffs, colour and texture similar to stem. Inflorescence borne singly, spathes green, umbels $1-6$ flowered, each umbel remain subtended by two opposite bracts, outer ones $1.5-4.5$ $\mathrm{cm}$ long, larger, enclosing the inner one and connoted at the summit, glabrous; pedicels 1.6$2.7 \mathrm{~cm}$ long, spreading, incurved lately; perianth urceolate, flaring open at distal, campanulate basally, pale-violate with purple stripes or yellow with rosy purple bases, outer tepals $9-11$ x $3-5 \mathrm{~mm}$, inner tepals $8-10 \times 2.5-4 \mathrm{~mm}$, oblong, slightly obovate, entire, acute; filaments 
fused basally; Ovary green, ca. $2 \times 1.2 \mathrm{~mm}$. Capsules tawny with brownish sutures, \pm globose, $2-4 \mathrm{~mm}$ in diam., pubescent or glabrous; seeds $0.5-1 \mathrm{~mm}, \pm$ globose, occasionally with slight depression at one side, black.

FLOWERING AND FRUITING: March - October

DISTRIBUTION: Native of the southernmost part of the North America along the coast of Gulf of Mexico/ Atlantic Ocean covering many US states [Texas, Louisiana, Mississippi, Alabama, Georgia, N \& S Carolina, Florida and Virginia. North and South America]; widely naturalized in many countries like Australia, New Caledonia, New Zealand, Fiji, Easter Island, Java, New Guinea, China, Georgia, Hawaii, Africa, Tibet, France, Spain, Japan, Korea, Italy, Italy, Puerto Rico, Virgin Islands and India [Shinners, 1962; Parent 1977, 1980; Goldblatt \& Henrich 1991; Wagner et al., 1999; Sunil \& Pradeep, 2011; Wang et al., 2012; Cardiel, 2011; Verloove \& Gullón 2012; Nicolella \& Ardenghi 2013; http://plantnet.rbgsyd.nsw.gov.au/cgiin/NSWfl.pl?page $=$ nswfl\&lvl $=$ sp\&name $=$ Sisyrinchium $\sim$ rosulatum] and now in Bhutan (Thimphu and Bumthang).

ECOLOGY: Sisyrinchium rosulatum in Bhutan grows along the roadsides and grasslands of elevation up to $3000 \mathrm{~m}$ in association Rumex nepalensis Spreng., Plantago depressa Willd., Oxalis corniculata L., Trifolium repens L., Prunella vulgaris L., Hypoxis aurea Lour., Juncus inflexus L., Anaphalis nepalensis (Spreng.) Hand.-Mazz., Senecio raphanifolius Wall. ex DC., Potentilla lineata Trevir., etc.

Note: The plant shows nyctinasty and dimorphic behavior, where partial closing of tepals at night and cloudy days was noted. The populations of species reported here is very rare and highly fragmented and it was noted from four districts of the country during the present study, but it might be present in other districts having similar habitats. Populations of newly naturalized species is expanding over the years and invasion of such alien species in the natural habitats can threaten the population of native species. Close monitoring on its invasion and population trend in the natural habitat is necessary to avoid threatening of endangered and native species.

\section{Acknowledgements}

The authors thank Dr. David G. Long (Royal Botanic Garden, Edinburgh), Dr. Alan R. Franck (Department of Biological Science, Florida) and Mrs. Sangay Dema (National Biodiversity Centre, Serbithang, Thimphu) for confirming the identity of the plant and providing valuable comments on the draft manuscript. The authors are also grateful to Mr. Dorji Gyeltshen (Watershed Management Division), Mr. Ngawang Gyeltshen (Nature Conservation Division) and Lekey Dorji (Divisional Forest Office, Trashigang) for support and guidance.

\section{LITERATURE CITED}

Bicknell, E.P. 1899. Studies in Sisyrinchium-I: Sixteen New Species from the Southern States. Bull. Torr. Bot. Cl. 26(5): 217 - 231. http://www.jstor.org/stable/2477747

Cardiel, J.M. 2011 Sisyrinchium L. In: Castroviejo, S. et al., Flora Iberica: plantas vasculares de la Peninsula Iberica e Islas Baleares. XX. Real Jardin Botanico, C.S.I.C., Madrid. Disp. On line: http://www.floraiberica.es/floraiberica/texto/imprenta/ tomoXX/20_185_00_Sisyrinchium.pdf.

Chauveau, O.; Eggers, L.; Raquin, C; Silverio, A.; Brown, S.; Couloux, A.A.; Cruaud, C.; Kaltchuk-Santos, E.; Yockteng, R.; Souza-Chies, T.T. \& Nadot, S. 2011. Evolution of oil-producing trichomes in Sisyrinchium (Iridaceae): insights from the first comprehensive phylogenetic analysis of the genus. Ann. Bot. 107: 1287-1312. 
Chauveau, O.; Eggers, L.; Raquin, C; Silverio, A.; Brown, S.; Couloux, A.A.; Cruaud, C.; Kaltchuk-Santos, E.; Yockteng, R.; Souza-Chies, T.T. \& Nadot, S. 2011. Evolution of oil-producing trichomes in Sisyrinchium (Iridaceae): insights from the first comprehensive phylogenetic analysis of the genus. Annals of Botany 107: $1287-1312$.

Cholewa, A. \& Henderson, D. 1984. Biosystematics of Sisyrinchium section Bermudiana (Iridaceae) of the Rocky Mountains. Brittonia 36: 342 - 363.

Goldblatt, P.; Rudall, P. \& Henrich, J.E. 1990. The genera of the Sisyrinchium Alliance (Iridaceae: Iridoideae): phylogeny and relationships. Syst. Bot. 15: $497-510$.

Goldblatt, P. \& Henrich, J.E. 1991. Calydorea Herbert (Iridaceae-Tigrideae): Notes on this New World genus and reduction to synonymy of Salpingostylis, Cardiostigma, Itysa and Catila. Ann. Miss. Bot. Gard. 78: 504 - 511.

Goldblatt, P. \& Manning, J. 2008. The Iris Family: Natural History and Classification. Timer Press, Portland, P. 290.

Henderson, D. 1976. A biosystematic study of Pacific Northwestern Blue Eyed grasses (Sisyrinchium, Iridaceae). Brittonia 28: 149 - 176.

http://plantnet.rbgsyd.nsw.gov.au/cgi-in/N SWfl.pl? page=nsw fl\&lvl=sp\&name $=$ Sisyrinchium $\sim$ rosulatum.

Nicolella, G. \& Ardenghi, N.M.G. 2013. Sisyrinchium rosulatum E.P.Bicknell (Iridaceae) alloctona nuova per 1'Italia. Acta Plantarum, Notes 2: $102-106$.

Noltie, H. 1994. Flora of Bhutan. Including a record of plants from Sikkim and Darjeeling. Vol. 3 part 1. Inverleith Row, Edinburgh, EH3 5LR, UK: Royal Botanic Garden Edinburgh.

Parent, G.H. 1977. Sisyrinchium rosulatum Bicknell dans les Landes. Bull. Centre Etudes Rech. Sci. Biarritz 11(3): 317 - 319.

Parent, G.H. 1980. Le genre Sisyrinchium L. (Iridaceae) en Europe. Un bilan provisoire. Lejeunia, n.s. 99.

PlantNET 2013. The NSW Plant Information Network System. Royal Botanic Gardens and Domain Trust, Sydney. http://plantnet.rbgsyd.nsw.gov.au

Rudall, P.; Kenton, A.Y. \& Lawrence, T.J. 1986. An Anatomical and Chromosomal Investigation of Sisyrinchium and Allied Genera. Bot. Gaz. 147: 466 - 477.

Shin, H.S.; Kim, M. \& Lee, N. 2016. First report of a newly naturalized Sisyrinchium micranthum and a taxonomic revision of Sisyrinchium rosulatum in Korea. Korean J. Pl. Tax. 46 (3): $295-300$.

Shinners, L.H. 1962. Annual Sisyrinchium (Iridaceae) in the United States. Sida 1(1): $32-42$.

Sunil, C.N. \& Pradeep, A.K. 2011: Sisyrinchium (Iridaceae): A new genus record for India. Rheedea 21(2): 170 - 172.

Verloove, F. \& Gullón, E.S. 2012: New records of interesting vascular plants (mainly xenophytes) in the Iberian Peninsula. II. Fl. Medit. 22: 5 - 24.

Wagner et al., 1999. Manual of the flowering plants of Hawai'i. Revised edn. University of Hawai'i Press, Bishop Museum Press.

Wang, S.L. et al., 2012. New records for Tibet. Acta Bot. Boreal.-Occid. Sin. 32: 1913 - 1914.

Yamaguchi, H. \& Hirai, S. 1987. Natural Hybridization and Flower Color Inheritance in Sisyrinchium rosulatum Bicknell. Weed Res., Japan 32 (1): 38 - 45. 